\title{
Calcium antagonism effects on cerebral blood flow in rats with acute hydrocephalus
}

\author{
Alexander Victor Shulyakov ${ }^{1,2^{*}}$, Richard J Buist ${ }^{3}$, Domenico L DiCurzio ${ }^{2,4}$, Marc Ronald Del Bigio ${ }^{1,2}$ \\ From Hydrocephalus 2015 \\ Banff, Canada. 18-21 September 2015
}

\section{Introduction}

Calcium ion antagonism shows some benefit in experimental hydrocephalus, but the interrelationship between the cerebral vasculature, cerebral blood flow $(\mathrm{CBF})$, and ventriculomegaly remains unclear.

\section{Methods}

Rats were injected with kaolin at 35 days and were studied after 12-15 days. CBF was measured with and without nimodipine or magnesium sulfate using magnetic resonance and fluorescent microspheres. Arterial blood and intracranial pressure (ICP), acid-base, oxygen/hemoglobin, and electrolytes status was measured. Intraparenchymal vascular remodeling was also determined in brains of hydrocephalic rats treated with calcium antagonists for 2 weeks.

\section{Results}

Increased ICP did not significantly affect cerebral perfusion pressure within the range of normal autoregulation. CBF significantly decreased in acutely hydrocephalic rats. Nimodipine and magnesium sulfate decreased systemic arterial blood pressure, cerebral perfusion and intracerebral pulse pressure; however, there was no change in cerebral blood flow. There was no change in white matter vascular density after 2 weeks treatment.

\section{Conclusions}

Cerebral hypoperfusion occurs in acute experimental hydrocephalus, however the calcium channel antagonists nimodipine and magnesium sulfate, do not increase the CBF. Reduced intracranial pulse pressure possibly mitigates development of acute hydrocephalus.

* Correspondence: ashulyakov@mich.ca

'Department of Pathology University of Manitoba, Canada

Full list of author information is available at the end of the article

\section{Authors' details}

'Department of Pathology University of Manitoba, Canada. ${ }^{2}$ Manitoba Institute of Child Health, Winnipeg, Canada. ${ }^{3}$ Department of Radiology, Faculty of Medicine University of Manitoba, Canada. ${ }^{4}$ Department of Human Anatomy \& Cell Science University of Manitoba, Canada.

Published: 18 September 2015

\section{References}

1. Alfasi AM, Shulyakov AV, Del Bigio MR: Intracranial biomechanics following cortical contusion in live rats. J Neurosurg 2013, 119(5):1255-62, doi: 10.3171/2013.7.JNS121973. Epub 2013 Sep 13.

2. Shulyakov AV, Del Bigio MR: Neurosurgery 2013, 72(5):E877-8, doi: 10.1227/ NEU.0b013e31828ab43c.

3. Shulyakov AV, Buist RJ, Del Bigio MR: Intracranial biomechanics of acute experimental hydrocephalus in live rats. Neurosurgery 2012, 71(5):1032-40, doi: 10.1227/NEU.0b013e3182690a0c.

doi:10.1186/2045-8118-12-S1-P49

Cite this article as: Shulyakov et al:: Calcium antagonism effects on cerebral blood flow in rats with acute hydrocephalus. Fluids and Barriers of the CNS 2015 12(Suppl 1):P49.
Submit your next manuscript to BioMed Central and take full advantage of:

- Convenient online submission

- Thorough peer review

- No space constraints or color figure charges

- Immediate publication on acceptance

- Inclusion in PubMed, CAS, Scopus and Google Scholar

- Research which is freely available for redistribution
() Biomed Central 